\title{
SOIL COVER PLANTS ON WATER EROSION CONTROL IN THE SOUTH OF MINAS GERAIS
}

\author{
Plantas de cobertura no controle da erosão hídrica no Sul de Minas Gerais
}

\author{
Adriana Cristina Dias ${ }^{1}$, Marx Leandro Naves Silva ${ }^{2}$, Diego Antonio França de Freitas ${ }^{3}$, \\ Pedro Velloso Gomes Batista ${ }^{1}$, Nilton Curi ${ }^{1}$, Gabriel José de Carvalho ${ }^{4}$
}

\begin{abstract}
Water erosion is responsible for soil, water, carbon and nutrient losses, turning into the most important type of degradation of Brazilian soils. This study aimed to evaluate the influence of three cover plants under two tillage systems on water erosion control in an Argisol at south of Minas Gerais state, Brazil. The cover plants utilized in the study were pigeon pea, jack bean and millet, under contour seeding and downslope tillage. Experimental plots of $4 \times 12 \mathrm{~m}$, with $9 \%$ slope, under natural rainfall were used for the quantification of losses of soil, water, nutrients, and organic matter. One experimental plot was kept without plant cover (reference). Higher erosivity was observed in December and January, although a great quantity of erosive rainfall was detected during the whole raining period. Contour seeding provided a greater reduction of water erosion than downslope tillage, as expected. The jack bean under contour seeding revealed the lowest values of soil, water, nutrients and organic matter losses.
\end{abstract}

Index terms: Soil conservation, tillage systems, vegetal cover, erosivity.

\section{RESUMO}

A erosão hídrica é responsável por perdas de solo, água, carbono orgânico e nutrientes, sendo esta a principal forma de degradação dos solos brasileiros. Dessa forma, objetivou-se, com este trabalho, avaliar a influência de três plantas de cobertura, em dois sistemas de manejo, no controle da erosão hídrica em um Argissolo, no sul de Minas Gerais. As plantas de cobertura utilizadas foram o feijão-guandu, feijão-de-porco e milheto, em dois sistemas de manejo (plantio em nível e em desnível no sentido do declive), sendo que uma parcela sem cobertura vegetal foi mantida como testemunha. Para a quantificação das perdas de solo, água, carbono orgânico e nutrientes utilizaram-se parcelas de 4 × $12 \mathrm{~m}$ em que a maior dimensão obedeceu ao sentido do declive, de $9 \%$, sob chuva natural. Os meses de dezembro e janeiro apresentaram a maior erosividade, porém elevada quantidade de chuvas erosivas foram detectadas durante todo o período chuvoso. O plantio em nível proporcionou maior redução da erosão hídrica em comparação ao plantio em desnível, conforme era de se supor. O feijão-de-porco cultivado em nível obteve os menores valores de perdas de solo, água, nutrientes e matéria orgânica.

Termos para indexação: Conservação do solo, sistemas de manejo, cobertura vegetal, erosividade.

(Received in may 15, 2013 and approved in june 24, 2013)

\section{INTRODUCTION}

The necessity of producing more food for an increasing population brought an intensification of land use, which led some soils in various regions of Brazil to impoverishment due to the accelerated erosion. Anthropogenic activity interferes with the erosive processes and practices such as contour seeding are able to reduce the magnitude of these processes (WANG et al., 2006).

Erosion is the process of detachment and carrying of soil particles caused by the actions of water and wind; water erosion is the most important cause of soil loss in Brazil (LESSA; LIMA; ZIMBACK, 2007). Erosion starts with the raindrop impact on the soil's surface, causing the breakdown of aggregates and subsequently the transportation of sediments, nutrients, water, and organic matter (TROEH; HOBBS; DANAHUE, 1980). Rainfall, if not controlled properly, disaggregates the soil, carrying considerable amounts of mineral particles and organic matter, which are essential to the soil productivity (SILVA; DE MARIA, 2011).

Due to the importance of water erosion in Brazil, many studies have been made in order to assess how different types of soil management strategies influence soil loss by erosion (COGO; LEVIEN; SCHWARZ, 2003; BERTOL et al., 2004; SILVA et al., 2005; AGUIAR et al., 2006; AQUINO et al., 2012; CARDOSO et al., 2012). However, water erosion is a complex process that occurs in varying intensity and it is influenced by factors such as

\footnotetext{
${ }^{1}$ Universidade Federal de Lavras/UFLA - Departamento de Ciência do Solo/DCS - Lavras - MG - Brasil

2Universidade Federal de Lavras/UFLA - Departamento de Ciência do Solo/DCS - Cx. P. 3037 - 37200-000 - Lavras - MG - Brasil - marx@dcs.ufla.br

${ }^{3}$ Universidade Federal de São João del-Rei/UFSJ - Campus Sete Lagoas - Sete Lagoas - MG - Brasil

${ }^{4}$ Universidade Federal de Lavras/UFLA - Departamento de Fitotecnia/DAG - Lavras - MG - Brasil
}

Ciênc. agrotec., Lavras, v. 37, n. 5, p. 410-418, set./out., 2013 
climate, soil, topography, vegetation, land use, and soil conservation and management practices (PIRES et al., 2006). Thus, in places where the rainfall erosivity is high and the soil surface presents sparse vegetation, large losses of soil, water, nutrients, and carbon may occur (CARDOSO et al., 2012).

In the southern region of Minas Gerais state, Brazil, where the topography is mostly undulated, rainfall precipitation is erosive and concentrated (AQUINO et al., 2012), and some soil classes favor the erosive process (AQUINO et al., 2013), the adoption of erosion control techniques is very important. Among these techniques, the use of cover plants for better soil surface protection stands out. According to Castro et al. (2011), the vegetative development of these plants, especially growth speed and efficient coverage of the soil surface, is related to morphological characteristics of leaves, crown canopy size, root development, growth habit, and crop residue.

The speed in which a particular plant covers the soil surface highly influences the erosive process. This occurs because in the initial growth period of crops, soil surface is unprotected and then susceptible to erosion. Thus, the analysis of rainfall erosivity and its relation to water erosion becomes highly important. Therefore, the aim of this study was to evaluate soil, water, nutrients, and organic matter losses under different tillage systems using cover plants in the South of Minas Gerais state, Brazil.

\section{MATERIAL AND METHODS}

The experimental plots were installed at Lavras, Minas Gerais, Brazil, located in the geographic coordinates $21^{\circ} 13^{\prime} 44^{\prime \prime}$ south latitude and $44^{\circ} 57^{\prime} 50^{\prime}$ ' west longitude (Figure 1), at an altitude of $925 \mathrm{~m}$. The climate is classified as Cwa by the Köppen climatic classification, characterized by rainy summers and dry winters, average annual rainfall of $1,530 \mathrm{~mm}$, and an average annual temperature of $19.4^{\circ} \mathrm{C}$.

The erosivity was calculated using rainfall precipitation data with 10 minutes interval, for the period from December 2010 to March 2011, obtained from the Lavras Main Climatological Station. Subsequently, the total kinetic energy of rainfall was calculated, according to Wischmeier and Smith (1958). The $\mathrm{EI}_{30}$ index was obtained by multiplying the total kinetic energy by the maximum intensity rainfall occurred in a consecutive period of 30 minutes $\left(\mathrm{I}_{30}\right)$. Rainfall separated by more than six hours with precipitation above than $1 \mathrm{~mm}$ was considered an individual rainfall event. Rainfall with less than $10 \mathrm{~mm}$, maximum intensity lower than $24 \mathrm{~mm} \mathrm{~h}^{-1}$ within 15 minutes, or with kinetic energy lower than 3.6 MJ was considered non-erosive (DE MARIA, 1994).
Seven experimental plots were installed in the field, six of them cultivated with cover plants: Millet (Pennisetumglaucum (L.) R. Brown) under downslope tillage (Mds) and under contour seeding (Mc), Pigeon Bean (Cajanuscajan (L.) Millsp) under downslope tillage (PBds) and under contour seeding (PBc), and Jack Bean (Canavaliaensiformis (L) DC) under downslope tillage (JBds) and under contour seeding (JBc). One plot was kept without plant coverage as a control plot (C) (Figure 1). The coverage crops were seeded in November 2010, with spacing of $0.5 \mathrm{~m}$ between lines. Fertilization and phytosanitary treatments were not performed throughout the crop cycle.

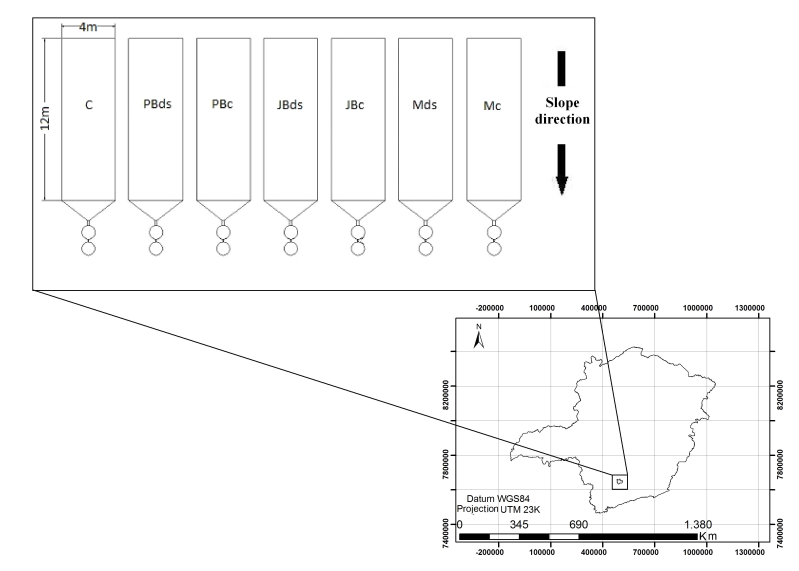

Figure 1 - Map location of the experimental plots at Lavras, southern state of Minas Gerais, Brazil, and outline of the experimental plots in the field (control plot - C, pigeon bean under downslope tillage - PBds, pigeon bean under contour seeding - PBc, jack bean under downslope tillage - JBds, jack bean under contour seeding - JBc, millet under downslope tillage-Mds, and millet under contour seeding - Mc), under natural rainfall conditions.

The soil in this study is classified as a Red-Yellow Argisol (EMPRESA BRASILEIRA DE PESQUISA AGROPECUÁRIA-EMBRAPA, 2006) or a Ultisol in the US Soil Taxonomy. Disturbed samples were used for chemical characterization (Table 1), which was determined according to Embrapa (1997), including: extractable cations ( $1 \mathrm{M} \mathrm{KCl}$ extractant for exchangeable $\mathrm{Ca}$ and $\mathrm{Mg} ; 0.05 \mathrm{M} \mathrm{HCl}+0.05 \mathrm{M} \mathrm{H}_{2} \mathrm{SO}_{4}$ extractant for available $\mathrm{K}$ and $\mathrm{P}$ ), and the soil organic carbon was determined by potassium dichromate oxidation and ferrous sulfate titration method, according to van Raij and Quaggio (1983). 
Table 1 - Characterization of soil chemical attributes of the experimental area, depth 0-20 cm.

\begin{tabular}{|c|c|c|c|c|c|}
\hline \multirow{2}{*}{ Treatment } & $\mathrm{P}$ & $\mathrm{K}^{+}$ & $\mathrm{Ca}^{2+}$ & $\mathrm{Mg}^{2+}$ & \multirow{2}{*}{$\begin{array}{c}\mathrm{SOM} \\
\ldots . \mathrm{g} \mathrm{kg}^{-1} \ldots .\end{array}$} \\
\hline & \multicolumn{2}{|c|}{$\ldots \ldots \ldots \ldots \ldots \mathrm{mg} \mathrm{dm}^{-3} \ldots \ldots \ldots \ldots \ldots$} & \multicolumn{2}{|c|}{$\ldots \ldots \ldots \ldots . \mathrm{cmol}_{\mathrm{c}} \mathrm{dm}^{-3} \ldots \ldots \ldots \ldots \ldots \ldots$} & \\
\hline $\mathrm{C}$ & 2.80 & 49.00 & 1.87 & 0.40 & 21.70 \\
\hline PBds & 2.17 & 35.67 & 1.30 & 0.30 & 15.70 \\
\hline $\mathrm{PBc}$ & 2.20 & 55.33 & 1.47 & 0.40 & 15.00 \\
\hline JBds & 2.30 & 56.66 & 1.26 & 0.40 & 17.70 \\
\hline $\mathrm{JBc}$ & 2.30 & 59.33 & 1.63 & 0.40 & 18.30 \\
\hline Mds & 2.00 & 53.00 & 1.47 & 0.40 & 17.70 \\
\hline $\mathrm{Mc}$ & 2.10 & 67.67 & 1.63 & 0.40 & 16.70 \\
\hline
\end{tabular}

$\mathrm{C}=$ Control; $\mathrm{PBds}=$ Pigeon Bean downslope; $\mathrm{PBc}=$ Pigeon Bean contour seeding; JBds = Jack Bean downslope; JBc $=\mathrm{Jack}$ Bean contour seeding; $\mathrm{Mds}=$ Millet downslope; $\mathrm{Mc}=$ Millet contour seeding; $\mathrm{SOM}=$ soil organic matter.

The Plant Cover Index (PCI) was determined according to the methodology described by Stocking (1988), using an apparatus equipped with 19 holes having $9 \mathrm{~mm}$ diameter each, spaced $10 \mathrm{~cm}$ from each other and arranged in a slit $2.0 \mathrm{~m}$ long and $1.20 \mathrm{~m}$ high. Evaluations were taken randomly and diagonally to the crop lines in three replications per plot. The value 0 (zero) was assigned for bare soil or debris vegetation; 0.5 for vegetation partially formed; and 1.0 for soil fully covered by vegetation. These determinations were carried with 15 days interval from seeding to the final phase of the crop cycle.

Data obtained from PCI was submitted to variance analysis and, when significant, Scott-Knott (1974) means test was utilized, with $\mathrm{p}>0.05$ significance, using SISVAR ${ }^{\circledR}$ software, developed by Ferreira (2011).

Soil nutrient and soil organic matter (SOM) losses, caused by superficial runoff, were quantified by the analysis of $\mathrm{P}, \mathrm{K}^{+}, \mathrm{Ca}^{2+}, \mathrm{Mg}^{2+}$ and $\mathrm{SOM}$ concentration on runoff sediments. Runoff enrichment rate (RER) was determined by dividing the values of nutrient content on runoff sediments by the contents obtained from the 0-20 $\mathrm{cm}$ depth of the original soil (HERNANI; KURIHARA; SILVA, 1999; SILVA et al., 2005). The Sediments Drag Potential (SDP) was calculated dividing soil losses $\left(\mathrm{t} \mathrm{ha}^{-1}\right)$ by water losses (mm) (MARTINS et al., 2003).

\section{RESULTS AND DISCUSSION}

Most of the rainfall that occurred was considered erosive, reaching $60 \%$ from the total rainfall events (Table 2 ), whereas $40 \%$ was considered non-erosive. Regarding the total rainfall precipitation, $96.72 \%$ were considered erosive, and $3.28 \%$ non-erosive. The highest incidence of total rainfall, erosive precipitation, and erosivity occurred during December, followed by the months of January, March and February.
Because of the high erosivity observed during the months of December and January, soil conservation practices should be implemented in the region, avoiding soil surface exposure to erosive agents. Nevertheless, every month considered in the study presented erosivity above $500 \mathrm{MJ} \cdot \mathrm{mm} \cdot \mathrm{ha}^{-1} \cdot \mathrm{h}^{-1} \cdot \mathrm{month}^{-1}$, which is the value considered critical by Rufino (1986).

Thus, high values of water erosion may occur during the months of February and March, and soil conservation practices should be extended during the whole rainy season in the southern region of Minas Gerais. Silva et al. (2005), Silva et al. (2010), Castro et al. (2011), and Cardoso et al. (2012) also registered high rainfall erosive potentials during the period of November thru March in the Minas Gerais state.

In general, the planting method (contour seeding or downslope tillage) did not influence the cover plants growth, when analyzed within the same species (Table 3 ). The jack bean presented faster initial growth than the other cover plants, aspect observed at 29 and 41 days after sowing (DAS) and the highest average plant cover index values. According to Cardoso et al. (2012), jack bean has a faster growth habit and alternate leaves with large elliptical-oval leaflets interspersed between themselves, which makes this species able to provide high vegetation coverage and greater potential to control the erosive process. Therefore, after soil preparation, the higher the speed a plant covers the soil, the more effective this plant will be at controlling erosion.

The millet showed the lowest plant cover index, possibly because it has a slow initial growth and an erect growth habit. Sodré Filho et al. (2004) observed low plant cover index values for millet during the first $30 \mathrm{DAS}$. Lopes, Cogo And Levien (1987) highlighted that an average PCI above $30 \%$ may be considered efficient in reducing soil loss by water erosion. Since millet presented an average PCI below $30 \%$ it was not framed as an efficient soil protector. 
Table 2 - Monthly values of total rainfall precipitation, erosive and non-erosive events, and erosivity during the period of December 2010 to March 2011, at Lavras, MG.

\begin{tabular}{|c|c|c|c|c|}
\hline \multirow{3}{*}{ Month/year } & \multicolumn{3}{|c|}{ Rainfall Precipitation and Events } & \multirow{2}{*}{ Erosivity } \\
\hline & Total & Erosive & Non-erosive & \\
\hline & \multicolumn{3}{|c|}{---------------------- mm (events) ------------------- } & MJ.mm.ha ${ }^{-1} \cdot h^{-1} \cdot$ month $^{-1}$ \\
\hline $\operatorname{Dec} / 2010$ & $343.3(17)$ & $338.2(12)$ & $5.1(5)$ & $3,515.25$ \\
\hline $\mathrm{Jan} / 2011$ & $340.4(15)$ & $334.9(12)$ & $5.5(3)$ & $2,074.84$ \\
\hline $\mathrm{Feb} / 2011$ & $85.3(6)$ & $81.3(3)$ & $4.0(3)$ & 649.17 \\
\hline Mar/2011 & $303.7(17)$ & $283.1(6)$ & $20.6(11)$ & $1,078.82$ \\
\hline Total & $1,072.7(55)$ & $1,037.5(33)$ & $35.2(22)$ & $7,318.08$ \\
\hline
\end{tabular}

Table 3 - Plant Cover Index (PCI) related to days after sowing (DAS) of pigeon bean under downslope tillage (PBds), pigeon bean under contour seeding $(\mathrm{PBc})$, jack bean under downslope tillage (JBds), jack bean under contour seeding $(\mathrm{JBc})$, millet under downslope tillage (Mds) and millet under contour seeding $(\mathrm{Mc})$.

\begin{tabular}{ccccccccc}
\hline & \multicolumn{7}{c}{ DAS } \\
\cline { 2 - 9 } Cover plants & 0 & 20 & 29 & 41 & 74 & 80 & 115 & Average \\
\cline { 2 - 9 }$y$ & & \multicolumn{7}{c}{ PCI (\%) } \\
PBds & 0 & $14.91 \mathrm{a}$ & $14.91 \mathrm{~b}$ & $21.93 \mathrm{~b}$ & $50.00 \mathrm{a}$ & $54.39 \mathrm{a}$ & $71.05 \mathrm{a}$ & 32.46 \\
PBc & 0 & $13.16 \mathrm{a}$ & $21.05 \mathrm{~b}$ & $23.68 \mathrm{~b}$ & $51.75 \mathrm{a}$ & $40.25 \mathrm{a}$ & $76.26 \mathrm{a}$ & 32.33 \\
JBds & 0 & $19.30 \mathrm{a}$ & $37.72 \mathrm{a}$ & $36.84 \mathrm{a}$ & $65.79 \mathrm{a}$ & $53.51 \mathrm{a}$ & $54.39 \mathrm{~b}$ & 37.48 \\
JBc & 0 & $11.40 \mathrm{a}$ & $28.87 \mathrm{a}$ & $35.09 \mathrm{a}$ & $63.16 \mathrm{a}$ & $52.63 \mathrm{a}$ & $50.00 \mathrm{~b}$ & 34.83 \\
Mds & 0 & $5.26 \mathrm{~b}$ & $12.28 \mathrm{~b}$ & $11.40 \mathrm{~b}$ & $28.45 \mathrm{a}$ & $29.82 \mathrm{~b}$ & $25.44 \mathrm{c}$ & 18.43 \\
Mc & 0 & $7.02 \mathrm{~b}$ & $14.04 \mathrm{~b}$ & $16.67 \mathrm{~b}$ & $46.49 \mathrm{a}$ & $45.61 \mathrm{a}$ & $30.70 \mathrm{c}$ & 22.37 \\
\hline CV (\%) & - & 30.55 & 26.47 & 34.1 & 23.54 & 17.81 & 23.33 & - \\
SD & - & 2.09 & 3.26 & 4.78 & 6.92 & 4.87 & 6.83 & - \\
\hline
\end{tabular}

Means followed by the same letter, in columns, do not differ themselves statistically by the Scott-Knott test, at 5\% probability level; $\mathrm{CV}=$ Coefficient of Variation; $\mathrm{SD}=$ Standard Deviation.

The monthly soil and water losses were higher in March, followed by December, January and February, except by the soil losses for pigeon bean and the jack bean under contour seeding (Table 4), and the water losses for jack bean under contour seeding (Table 5). In March, after several months of rain, the soil is probably more saturated and has a reduced rate of water infiltration, provoking an increase of runoff; resulting in high levels of soil and water losses (OLIVEIRA et al., 2013). When studying how agroforestry systems reduce the intensity of erosive agents, Aguiar et al. (2006) observed that sediments and water losses were concentrated during the end of the rainy period, due to the previous soil moisture. Silva et al. (2009) concluded that the highest risks related to water erosion occur between November and March, due to the greater rainfall erosive potential and the preceding soil moisture.
Pigeon bean and jack bean under contour seeding had greater soil losses in December, followed by March, January and February. These plants, both under contour seeding, were efficient at the control of water erosion even with the probably saturated soil in March. Pigeon bean and jack bean under contour seeding had greater soil losses in December, followed by March, January and February. These plants, both under contour seeding, were efficient at the control of water erosion even with the probably saturated soil in March.

In December soil losses are high due to elevated rainfall, erosivity, and incipience of the vegetation coverage. During the month of January there is high erosivity and rainfall, but the soil is already partially covered by vegetation. The lowest losses, coinciding with the lowest rainfall and erosivity levels determined during the experimental period, were observed in 
Table 4 - Soil loss $\left(\mathrm{Mg} \mathrm{ha}^{-1}\right)$ from control plot $(\mathrm{C})$, pigeon bean under downslope tillage (PBds), pigeon bean under contour seeding $(\mathrm{PBc})$, jack bean under downslope tillage (JBds), jack bean under contour seeding (JBc), millet under downslope tillage (Mds) and millet under contour seeding $(\mathrm{Mc})$.

\begin{tabular}{lccccccc}
\hline \multicolumn{1}{c}{ Month/Year } & \multicolumn{7}{c}{ Treatments } \\
\hline & $\mathrm{C}$ & PBds & PBc & JBds & JBc & Mds & Mc \\
\hline December/2010 & 2.1059 & 1.3956 & 1.3069 & 1.1263 & 0.3703 & 1.3440 & 1.1934 \\
January/2011 & 0.9195 & 0.3282 & 0.2528 & 0.4199 & 0.1140 & 0.4241 & 0.3317 \\
February/2011 & 0.1514 & 0.0000 & 0.0000 & 0.0000 & 0.0000 & 0.0893 & 0.1182 \\
March/2011 & 4.4967 & 1.9068 & 0.7605 & 1.2590 & 0.2362 & 2.4797 & 2.1882 \\
\hline Total & 7.6735 & 3.6306 & 2.3202 & 2.8052 & 0.7205 & 4.3371 & 3.8315 \\
Average & 1.9184 & 0.9077 & 0.5801 & 0.7013 & 0.1801 & 1.0843 & 0.9571 \\
\hline
\end{tabular}

Table 5 - Total and monthly values of water loss $(\mathrm{mm})$ from control plot $(\mathrm{C})$, pigeon bean under downslope tillage (PBds), pigeon bean under contour seeding (PBc), jack bean under downslope tillage (JBds), jack bean under contour seeding (JBc), millet under downslope tillage (Mds) and millet under contour seeding (Mc).

\begin{tabular}{lccccccc}
\hline \multicolumn{1}{c}{ Month/Year } & \multicolumn{7}{c}{ Treatments } \\
\hline & $\mathrm{C}$ & PBds & PBc & JBds & JBc & Mds & Mc \\
\hline December/2010 & 16.20 & 16.00 & 15.71 & 15.86 & 15.61 & 16.58 & 15.91 \\
January/2011 & 10.28 & 10.28 & 10.28 & 10.28 & 10.28 & 10.28 & 10.28 \\
February/2011 & 2.13 & 0.00 & 0.00 & 0.00 & 0.12 & 1.94 & 1.62 \\
March/2011 & 61.80 & 52.73 & 52.20 & 52.29 & 2.19 & 53.46 & 53.55 \\
\hline Total & 90.41 & 79.01 & 78.19 & 78.43 & 28.20 & 82.26 & 81.36 \\
Average & 22.60 & 19.75 & 19.55 & 19.61 & 7.05 & 20.55 & 20.34 \\
\hline
\end{tabular}

February. Several authors report that the highest soil and water losses occur in December, due to high rainfall and erosivity in the central region of Brazil (CARVALHO et al., 2009; SILVA et al., 2009; SILVA et al., 2010), which was not confirmed here, probably due to the more effective plant cover.

The total losses of soil and water showed the following trend: bare soil $>$ millet under downslope tillage $>$ millet under contour seeding $>$ pigeon pea under downslope tillage $>$ jack bean under downslope tillage $>$ pigeon pea under contour seeding $>$ jack bean under contour seeding (Table 4). These results corroborate those of Cogo, Levien and Schwarz (2003), indicating that the plant cover offers the necessary protection to the soil during highly erosive rainfall events.

Contour seeding proved to be a more effective soil conservation practice than downslope tillage, provoking less soil loss under all three cover plants conditions (Table 4). Similar results were determined by Carvalho et al. (2009), when evaluating soil loss by water erosion from velvet-bean, sunn, corn under contour seeding, corn under downslope tillage and bare soil, for different types of soil preparation, in a Red-Yellow Argisol, at Seropédica, Rio de Janeiro, Brazil. Pires et al. (2006) reported a decrease in runoff speed and volume in crops under contour seeding, because this practice favors water infiltration by subdividing the length of the slope and by increasing the rugosity of the terrain, and then the water retention capacity. Thus, due to the considerable decrease in soil and water loss on contour seeding systems, it is safe to recommend this type of soil conservation practice.

When planted under contour seeding, jack bean presented higher potential for the control of soil and water 
losses. Millet showed the least effectiveness for the control of water erosion, regardless of the tillage method. Similar results were determined by Cardoso et al. (2012), where the jack bean was the plant with the greatest performance on the control of the erosive process.

The sediments drag potential (SDP) varied from $0.0849 \mathrm{Mg} \mathrm{ha}^{-1} \mathrm{~mm}^{-1}$ on the control plot to $0.0255 \mathrm{Mg} \mathrm{ha}^{-1}$ $\mathrm{mm}^{-1}$ on the jack bean under contour seeding plot (Figure 2). As it happened with soil and water losses, the jack bean under contour seeding was the crop which provided the greatest protection to the soil, corroborating its low SDP values. Consequently, this plant proved to be effective on the control of soil erosion, regardless of the tillage method, but the lowest SDP values happened on contour seeding. Cardoso et al. (2012) affirm that the jack bean is the crop that provides the lowest SDP values at the southern region of Minas Gerais state.

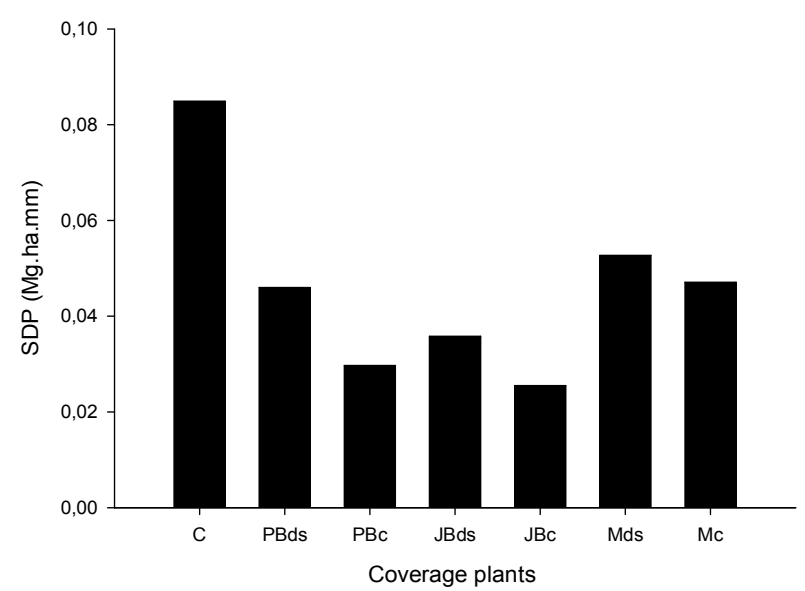

Figure 2 - Sediments Drag Potential (SDP) from control plot $(\mathrm{C})$, pigeon bean under downslope tillage (PBds), pigeon bean under contour seeding $(\mathrm{PBc})$, jack bean under downslope tillage (JBds), jack bean under contour seeding $(\mathrm{JBc})$, millet under downslope tillage (Mds) and millet under contour seeding (Mc).

The runoffenrichment rate(RER) indicates an increase or a decrease on the organic carbon concentration, on sediments analyses, and nutrients, on sediments and runoff analyses, in comparison to the soil. RER above 1.0 indicates that the concentration of eroded sediments is higher than on the original soil, characterizing the selectivity of the dragging material in the process of water erosion, which transports mainly finer particles, the more reactive soil fraction, and consequently the more capable of carrying nutrients and organic carbon (HERNANI; KURIHARA; SILVA, 1999; SILVA etal., 2005).
However, in this experiment there was no enrichment of $\mathrm{Ca}^{2+}$ and $\mathrm{Mg}^{2+}$ on the runoff (Table 6). The $\mathrm{Ca}^{2+}$ and $\mathrm{Mg}^{2+}$ are nutrients lost in greater quantity thru the solution, due to their high mobility in the soil profile. They are mobile nutrients, liable to leaching at depth, and less liable to be lost by runoff, thus not contributing to the enrichment of the runoff studied in this experiment.

Table 6 - Runoff enrichment rate of the Red-Yellow Argisol, under control plot (C), pigeon bean under downslope tillage (PBds), pigeon bean under contour seeding $(\mathrm{PBc})$, jack bean under downslope tillage (JBds), jack bean under contour seeding (JBc), millet under downslope tillage (Mds) and millet under contour seeding (Mc).

\begin{tabular}{cccccc}
\hline Treatments & $\mathrm{P}$ & $\mathrm{K}^{+}$ & $\mathrm{Ca}^{2+}$ & $\mathrm{Mg}^{2+}$ & $\mathrm{SOM}$ \\
\hline $\mathrm{C}$ & 0.1 & 2.2 & 0.7 & 0.7 & 1.7 \\
PBds & 3.9 & 2.2 & 0.5 & 0.5 & 1.4 \\
PBc & 4.9 & 1.5 & 0.4 & 0.5 & 1.4 \\
JBds & 5.9 & 2.2 & 0.6 & 0.7 & 1.6 \\
JBc & 0.0 & 0.0 & 0.0 & 0.7 & 0.0 \\
Mds & 6.7 & 3.2 & 0.5 & 0.7 & 2.7 \\
Mc & 6.3 & 2.0 & 0.5 & 0.6 & 2.1 \\
\hline
\end{tabular}

The control plot and the treatment with jack bean under contour seeding did not show P enrichment; in the first case it happened because the high dilution, due to high levels of water and soil loss. For the jack bean under contour seeding, the low RER occurred due to the reduced soil and water losses (Tables 4 and 5). According to Cardoso et al. (2012), the loss of P by erosion happens thru the drag of soil particles, because this element is mainly encountered adsorbed to soil colloids.

The concentration of the soil organic matter on eroded sediments was higher than the concentration on the soil, demonstrated by the value of the RER above 1.0 (Table 6). Similar results were found by Bertol et al. (2004) and Silva et al. (2005). These authors affirm that these results might be explained by the high affinity between the clay fraction and the organic carbon, propitiating a selective type of erosion, where the colloidal mineral fraction and the organic matter are the first soil constituents to be removed by water erosion, in view of their low density. 
Due to the high RER by organic carbon, it becomes important to emphasize the necessity of soil conservation practices that help reduce the rainfall erosive action, maintaining the organic fraction on the soil, due to its importance its importance upon moisture retention, cation exchange capacity, and maintenance of the soil's chemical and physical properties, among other attributes.

Millet under downslope tillage showed the highest RER for $\mathrm{P}, \mathrm{K}^{+}$and SOM (Table 6), because this planting system and this crop did not offer high soil protection to water erosion, and it was not considered to be a good alternative for soil conservation in the southern region of Minas Gerais state.

In general, most nutrient losses on sediments caused by water erosion presented the following sequence: $\mathrm{Ca}>\mathrm{K}>\mathrm{Mg}>\mathrm{P}$ (Table 7). Similar results were observed by Silva et al. (2005), Hernani, Kurihara and Silva (1999) and Aguiar et al. (2006). P loss occurred in lower quantities, because this element is mostly encountered adsorbed on colloids and it is mainly removed when soil particles are dragged, according to Cardoso et al. (2012).

$\mathrm{K}^{+}$loss is related to this nutrient's content in the soil and its lower fixation capacity by clay minerals, facilitating its transportation by the runoff (AGUIAR et al., 2006). The control plot presented very low values of $\mathrm{P}$ loss (Table 7), probably due to the dilution that occurs by relating the quantity of $\mathrm{P}$ in runoff to the high levels of soil and water losses. The greater losses of $\mathrm{K}^{+}, \mathrm{Ca}^{2+}$, and $\mathrm{Mg}^{2+}$ were observed on the tillage systems where soil conservation practices were not effective, as the bare soil on the control plot and the millet plots. This fact occurs because among the many variables which interfere with the erosive process, plant coverage is the isolated factor which has the greatest influence, and can be provided by plant residues in soil and/or by plant canopy above the soil (FOSTER, 1982; SEGANFREDO; ELTZ; BRUM, 1997).

The jack bean was the coverage plant which provided the lowest losses of de $\mathrm{P}, \mathrm{K}^{+}, \mathrm{Ca}^{2+}, \mathrm{Mg}^{2+}$, and soil organic matter, when planted under contour seeding (Table 7). The results provided by this plant are related to its effectiveness in protecting the soil from the direct impact of raindrops (Table 3), combined to the tillage system that reduces runoff and favors water infiltration. Altogether, all cover plants under contour seeding showed lesser losses of organic carbon and nutrients than when planted downslope. Similar results were found by Silva et al. (2005) and Cardoso et al. (2012).

Table 7 - Total losses of $\mathrm{P}, \mathrm{K}^{+}, \mathrm{Ca}^{2+}, \mathrm{Mg}^{2+}$ and soil organic matter (SOM) from the Red-Yellow Argisol, under control plot (C), pigeon bean under downslope tillage (PBds), pigeon bean under contour seeding (PBc), jack bean under downslope tillage (JBds), jack bean under contour seeding (JBc), millet under downslope tillage (Mds) and millet under contour seeding $(\mathrm{Mc})$, under natural rainfall conditions at Lavras, $\mathrm{MG}$.

\begin{tabular}{lccccr}
\hline \multirow{2}{*}{ Treatments } & $\mathrm{P}$ & $\mathrm{K}^{+}$ & $\mathrm{Ca}^{2+}$ & $\mathrm{Mg}^{2+}$ & $\mathrm{SOM}$ \\
\cline { 2 - 5 } & $-0 .-1.208$ & 0.145 & 0.19 \\
\hline $\mathrm{C}$ & 0.002 & 0.266 & 0.492 & 0.066 & 0.07 \\
PBds & 0.034 & 0.200 & 0.304 & 0.046 & 0.05 \\
PBc & 0.027 & 0.186 & 0.377 & 0.057 & 0.06 \\
JBds & 0.040 & 0.297 & 0.000 & 0.014 & 0.00 \\
JBc & 0.000 & 0.000 & 0.506 & 0.087 & 0.08 \\
Mds & 0.051 & 0.343 & 0.511 & 0.077 & 0.07 \\
Mc & 0.048 & 0.367 & & & \\
\hline
\end{tabular}




\section{CONCLUSIONS}

The high levels of erosivity that occurred during the whole rainy period help to explain the high levels of water erosion on bare soils.

The contour seeding afforded better protection against water erosion than downslope tillage for cover plants.

The jack bean under contour seeding provided the greatest reduction of soil, water, nutrients and soil organic matter losses, and it is strongly recommended as soil cover plant in this region of study.

\section{ACKNOWLEDGMENTS}

To the Research Support Foundation of Minas Gerais-FAPEMIG, to the Coordination for the Improvement of Higher Level Education - CAPES, and to the National Council for the Technological and Scientific Development $-\mathrm{CNPq}$.

\section{REFERENCES}

AGUIAR, M.I. et al. Perdas de solo, água e nutrientes em sistemas agroflorestais no município de Sobral, CE.

Revista Ciência Agronômica, Fortaleza, v.37, n.3, p.270278, maio/jun. 2006.

AQUINO, R.F. et al. Spatial variability of the rainfall erosivity in southern region of Minas Gerais state, Brazil. Ciência e Agrotecnologia, Lavras, v.36, n.5, p.533-542, sept./oct. 2012.

AQUINO, R.F. et al. Soil losses from typic Cambisols and Red Latosol as related to three erosive rainfall patterns. Revista Brasileira de Ciência do Solo, Viçosa, v.37, n.1, p.213-220, jan./feb. 2013.

BERTOL, I. et al. Perdas de fósforo e potássio por erosão hídrica em um Inceptisol sob chuva natural. Revista Brasileira de Ciência do Solo, Viçosa, v.28, n.1, p.485494, jan./feb. 2004.

CARDOSO, D.P. et al. Plantas de cobertura no controle das perdas de solo, água e nutrientes por erosão hídrica. Revista Brasileira de Engenharia Agrícola e Ambiental, Campina Grande, v.16, n.6, p.632-638, nov./ dec. 2012.

CARVALHO, D. F. de et al. Características da chuva e perdas por erosão sob diferentes práticas de manejo do solo. Revista Brasileira de Engenharia Agrícola e
Ambiental, Campina Grande, v.13, n.1, p.3-9, jan./fev. 2009.

CASTRO, N.E.A. et al. Plantas de cobertura no controle da erosão hídrica sob chuvas naturais. Biosciencie Journal, Uberlândia, v.27, n.5, p.775-785, set./out. 2011.

COGO, N.P.; LEVIEN, R.; SCHWARZ, R.A. Perdas de solo e água por erosão hídrica influenciadas por métodos de preparo, classes de declive e níveis de fertilidade do solo. Revista Brasileira de Ciência do Solo, Viçosa, v.27, n.4, p.743-753, jul./ago. 2003.

DE MARIA, I.C. Cálculo da erosividade da chuva. In: INSTITUTO AGRONÔMICO DE CAMPINAS. Manual de programas de processamento de dados de campo e de laboratório para fins de experimentação em conservação do solo. Campinas: IAC/SCS, 1994. Não paginado.

EMPRESA BRASILEIRA DE PESQUISA

AGROPECUÁRIA- EMBRAPA. Manual de métodos de análises de solos. 2. ed. Rio de Janeiro: Embrapa Solos, 1997, 212p.

EMPRESA BRASILEIRA DE PESQUISA AGROPECUÁRIA-EMBRAPA. Sistema Brasileiro de classificação de solos. 2. ed. Rio de Janeiro: Embrapa Solos, 2006, 306p.

FERREIRA, D.F. Sisvar: a computer statistical analysis system. Ciência e Agrotecnologia, Lavras, v.35, n.6, p.1039-1042, nov./dec. 2011.

FOSTER, G.R. Modeling the erosion process. In: HAAN, J.; BRAKENSIEK. D.L. Hydrological Modeling of Small Watersheds. Michigan: American Society of Agricultural Engineering, p.297-300, 1982.

HERNANI, L.C.; KURIHARA, C.H.; SILVA, W.M. Sistemas de manejo de solo e perdas de nutrientes e matéria orgânica por erosão. Revista Brasileira de Ciência do Solo, Viçosa, v.23, n.1, p.145-154, jan./ fev, 1999.

LESSA, L.G.F.; LIMA, S.L.; ZIMBACK, C.R.L. Análise multitemporal das perdas de solo por voçorocas da subbacia Ribeirão das Bicas - Botucatu/SP, através de geoprocessamento e sensoriamento remoto. Energia na Agricultura. Botucatu, v.22, n.2, p.61-74, jul. 2007. 
LOPES, P.R.; COGO, N.P.; LEVIEN, R. Eficácia relativa de tipo e quantidade de resíduos culturais espalhados uniformemente sobre o solo na redução da erosão hídrica. Revista Brasileira de Ciência do Solo, Campinas, v.11, n.1, p.71-75, jan./abr. 1987.

MARTINS, S.G. et al. Perdas de solo e água por erosão hídrica em sistemas florestais na região de Aracruz (ES). Revista Brasileira de Ciência do Solo, Viçosa, v.27, n.1, p.395-403, jan./fev. 2003.

OLIVEIRA, A.H. et al. Water erosion in soils under eucalyptus forest as affected by development stages and management systems. Ciência e Agrotecnologia, Lavras, v.37, n.1, p.159-169, jan./feb. 2013.

PIRES, L. S. et al. Erosão hídrica pós-plantio emflorestas de eucalipto na região centro-leste de Minas Gerais.

Pesquisa Agropecuária Brasileira, Brasília, v.41, n.4, p.687-695, abr. 2006.

RUFINO, R.L. Avaliação do potencial erosivo da chuva para o estado do Paraná. Revista Brasileira de Ciência do Solo, Campinas, v.10, n.3, p.279-281, maio/jun. 1986.

SEGANFREDO, M.L.; ELTZ, F.L.F.; BRUM, A.C.R. Perdas de solo, água e nutrientes por erosão em sistemas de culturas em plantio direto. Revista Brasileira de Ciência do Solo, Viçosa, v.21, n.3, p.287291, maio/jun. 1997.

SCOTT, A.J.; KNOTT, M.A. A cluster analysis method for grouping means in the analysis of variance. Biometrics, New York, v.30, n.4, p.507-512, dec. 1974.

SILVA, A.M. et al. Erosividade da chuva e erodibilidade de Cambissolo e Latossolo na região de Lavras, sul de Minas Gerais. Revista Brasileira de Ciência do Solo, Viçosa, v.33, n.6, p.1811-1820, nov./dec. 2009.

SILVA, M.A. et al. Avaliação e espacialização da erosividade da chuva no Vale do Rio Doce, região centro leste do estado de Minas Gerais. Revista Brasileira de Ciência do Solo, Viçosa, v.34, n.4, p.1029-1039, jul./Ago. 2010.

SILVA, R.L; DE MARIA, I.C. Erosão em sistema plantio direto: Influência do comprimento de rampa e da direção de semeadura. Revista Brasileira de Engenharia Agrícola e Ambiental, Campina Grande, v.15, n.6, p.554561, jun. 2011.

SILVA. A.M. et al. Perdas de solo, água, nutrientes e carbono orgânico em Cambissolo e Latossolo sob chuva natural. Pesquisa Agropecuária Brasileira. Brasília, v.40, n.12, p.1223-1230, dez. 2005.

SODRÉ FILHO, J. et al. Fitomassa e cobertura do solo de culturas de sucessão ao milho na Região do Cerrado. Pesquisa Agropecuária Brasileira, Brasília, v.39, n.4, p.327-334. abr. 2004.

STOCKING, M.A. Assessing vegetative cover and management effects. In: LAL, R. Soil erosion research methods. Ankeny: Soil and Water Conservation Society, 1988.p.163-185.

TROEH, F.R.; HOBBS, J.A.; DANAHUE, R.L. Soil and water conservation: for productivity and environmental protection. New Jersey: Prentice-Hall, 1980. 718p.

VAN RAIJ, B.; QUAGGIO, J.A. Métodos de análise de solo para fins de fertilidade. Campinas: IAC, Boletim Técnico n.81, 1983, 31p.

WISCHMEIR, W.H.; SMITH, D.D. Rainfall energy and its relationship to soil loss. Transactions American Geophisical Union, v.39, n.2, Washington, p.285-291, apr. 1958.

WANG, X. B. et al. Potential effect of conservation tillage on sustainable land use: A review of global long-term Studies. Pedosphere, Nanjing, v.16, n.5, p.587-595, oct. 2006. 